\title{
iMarNet: an ocean biogeochemistry model intercomparison project within a common physical ocean modelling framework
}

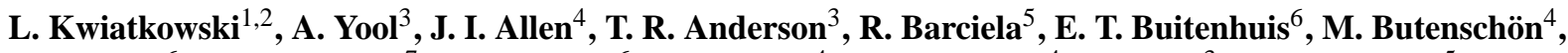 \\ C. Enright $^{6}$, P. R. Halloran ${ }^{7}$, C. Le Quéré ${ }^{6}$, L. de Mora ${ }^{4}$, M.-F. Racault ${ }^{4}$, B. Sinha ${ }^{3}$, I. J. Totterdell ${ }^{5}$, and P. M. Cox ${ }^{1}$ \\ ${ }^{1}$ College of Engineering, Mathematics and Physical Sciences, University of Exeter, Exeter EX4 4QF, UK \\ ${ }^{2}$ Department of Global Ecology, Carnegie Institution for Science, 260 Panama Street, Stanford, California 94305, USA \\ ${ }^{3}$ National Oceanography Centre, University of Southampton Waterfront Campus, European Way, \\ Southampton SO14 3ZH, UK \\ ${ }^{4}$ Plymouth Marine Laboratory, Prospect Place, West Hoe, Plymouth PL1 3DH, UK \\ ${ }^{5}$ Hadley Centre, Met Office, Exeter EX1 3PB, UK \\ ${ }^{6}$ Tyndall Centre for Climate Change Research, School of Environmental Sciences, University of East Anglia, Norwich, UK \\ ${ }^{7}$ College of Life and Environmental Sciences, University of Exeter, Exeter EX4 4RJ, UK
}

Correspondence to: L. Kwiatkowski (lkwiatkowski@carnegiescience.edu)

Received: 5 June 2014 - Published in Biogeosciences Discuss.: 10 July 2014

Revised: 15 November 2014 - Accepted: 17 November 2014 - Published: 19 December 2014

\begin{abstract}
Ocean biogeochemistry (OBGC) models span a wide variety of complexities, including highly simplified nutrient-restoring schemes, nutrient-phytoplanktonzooplankton-detritus (NPZD) models that crudely represent the marine biota, models that represent a broader trophic structure by grouping organisms as plankton functional types (PFTs) based on their biogeochemical role (dynamic green ocean models) and ecosystem models that group organisms by ecological function and trait. OBGC models are now integral components of Earth system models (ESMs), but they compete for computing resources with higher resolution dynamical setups and with other components such as atmospheric chemistry and terrestrial vegetation schemes. As such, the choice of OBGC in ESMs needs to balance model complexity and realism alongside relative computing cost. Here we present an intercomparison of six OBGC models that were candidates for implementation within the next UK Earth system model (UKESM1). The models cover a large range of biological complexity (from 7 to 57 tracers) but all include representations of at least the nitrogen, carbon, alkalinity and oxygen cycles. Each OBGC model was coupled to the ocean general circulation model Nucleus for European Modelling of the Ocean (NEMO) and results from physically identical hindcast simulations were compared. Model skill was evaluated for biogeochemical metrics of global-scale
\end{abstract}

bulk properties using conventional statistical techniques. The computing cost of each model was also measured in standardised tests run at two resource levels. No model is shown to consistently outperform all other models across all metrics. Nonetheless, the simpler models are broadly closer to observations across a number of fields and thus offer a highefficiency option for ESMs that prioritise high-resolution climate dynamics. However, simpler models provide limited insight into more complex marine biogeochemical processes and ecosystem pathways, and a parallel approach of lowresolution climate dynamics and high-complexity biogeochemistry is desirable in order to provide additional insights into biogeochemistry-climate interactions.

\section{Introduction}

Ocean biogeochemistry is a key part of the Earth system: it regulates the cycles of major biogeochemical elements and controls the associated feedback processes between the land, ocean and atmosphere. As a result, changes in ocean biogeochemistry can have important implications for climate (Reid et al., 2009). Marine ecosystems are indirectly affected by anthropogenic environmental change (Jackson et al., 2001), particularly through climate-induced changes 
Table 1. Biogeochemical cycles represented in each candidate model.

\begin{tabular}{lcccccc}
\hline & HadOCC & Diat-HadOCC & MEDUSA-2 & PlankTOM6 & PlankTOM10 & ERSEM \\
\hline $\mathrm{N}$ & $\sqrt{ }$ & $\sqrt{ }$ & $\sqrt{ }$ & $\sqrt{ }$ & $\sqrt{ }$ & $\sqrt{ }$ \\
$\mathrm{P}$ & & & & & $\sqrt{ }$ & $\sqrt{ }$ \\
$\mathrm{Si}$ & & $\sqrt{ }$ & $\sqrt{ }$ & $\sqrt{ }$ & $\sqrt{ }$ & $\sqrt{ }$ \\
$\mathrm{Fe}$ & & $\sqrt{ }$ & $\sqrt{ }$ & $\sqrt{ }$ & $\sqrt{ }$ & $\sqrt{ }$ \\
$\mathrm{C}$ & $\sqrt{ }$ & $\sqrt{ }$ & $\sqrt{ }$ & $\sqrt{ }$ & $\sqrt{ }$ & $\sqrt{ }$ \\
Alkalinity & $\sqrt{ }$ & $\sqrt{ }$ & $\sqrt{ }$ & $\sqrt{ }$ & $\sqrt{ }$ & $\sqrt{ }$ \\
$\mathrm{O}_{2}$ & $\sqrt{ }$ & $\sqrt{ }$ & $\sqrt{ }$ & $\sqrt{ }$ & $\sqrt{ }$ & $\sqrt{ }$ \\
\hline
\end{tabular}

in physical properties and $\mathrm{CO}_{2}$-induced ocean acidification. Understanding and quantifying the response of ocean biogeochemistry to global changes and their feedbacks with the Earth system is essential to improve our capacity to maintain ecosystem services this century and beyond.

With the recent publication of the Intergovernmental Panel on Climate Change (IPCC) fifth assessment report (AR5), global efforts are already underway to develop the next generation of Earth system models (ESMs) to support climate policy development and any further IPCC assessment report. Ocean biogeochemistry (OBGC) models coupled to ESMs can help address a series of overarching scientific questions such as: how will the ocean contribute to atmospheric trace gas composition (e.g. $\mathrm{CO}_{2}, \mathrm{CH}_{4}, \mathrm{~N}_{2} \mathrm{O}$, DMS) in a changing climate? Are there tipping points in marine biogeochemistry (e.g. oceanic anoxic events, methane hydrate release) that could be triggered by a changing climate? Are there interactions between ESM processes and society's management of resources (e.g. fisheries, land use, agriculture) in the marine environment? Furthermore, as ESMs are increasingly being evaluated based on their capacity to understand past variability (Braconnot et al., 2012), further questions might include: what controlled variations in atmospheric trace gas concentrations and isotopic composition over the geological past?

For an anticipated sixth IPCC assessment report it is generally agreed that these global-scale questions, with direct implications for climate policies, will again be the main focus of ocean biogeochemical models within ESMs. In addition, the ESM model archive is increasingly being used for activities within the Inter-Sectoral Impact Model Intercomparison Project (http://www.pik-potsdam. de/research/climate-impacts-and-vulnerabilities/research/ rd2-cross-cutting-activities/isi-mip/scientific-publications) to address socio-economically directed questions such as: How will climate change affect ocean primary production (e.g. Bopp et al., 2013), fisheries (Barange et al., 2014; Cheung et al., 2012) and harmful algal and jellyfish blooms (e.g. Codon et al., 2013, Gilbert et al., 2014)? What is the potential for geoengineering schemes such as ocean fertilisation (Buesseler and Boyd, 2003) and alkalinity addition (Kheshgi, 1995; Harvey, 2008) to affect the climate system, and how do they affect the rest of the Earth system?
Within the UK, the Integrated Global Biogeochemical Modelling Network (iMarNet) project aims to advance the development of ocean biogeochemical models through collaboration between existing modelling groups at Plymouth Marine Laboratory (PML), National Oceanography Centre (NOC), University of East Anglia (UEA) and the Met Office Hadley Centre (UKMO). As part of iMarNet we conducted an intercomparison of six current UK models to help inform the selection of a baseline OBGC model for the next UK Earth system model (UKESM1). This intercomparison focused on the ability of the model to reproduce globalscale bulk properties - such as nutrient and carbon distributions - that broadly characterise the activity of marine biota (and thus the carbon cycle) in the ocean. To limit the role of errors originating from modelled physics, all of the examined model simulations were performed within the same physical ocean general circulation model (GCM), under the same external forcing and following the same experimental protocol. As all of the models examined have been previously published, our analysis does not include an assessment of their underlying biological fidelity (i.e. the extent to which structures, parameterisations and parameter sets of candidate models are a priori realistic). However, while primarily focused on model skill, the intercomparison also considers the computational cost of the models in relation to the realism that they offer. Previous authors have performed biogeochemical model intercomparisons with parallels to this study (e.g. Friedrichs et al., 2007; Kriest et al., 2010; Steinacher et al., 2010; Popova et al., 2012). These have differed from this study and each other in a number of ways. For instance, this study is 3-D rather than 1D (cf. Friedrichs et al., 2007), global rather than regional (cf. Popova et al., 2012), uses identical rather than diverse physics (cf. Steinacher et al., 2010) and spans a more functionally diverse range of biogeochemical models (cf. Kriest et al., 2010). The latter two factors, in particular, distinguish this study, permitting us to both formally separate the impact of physics from that of biogeochemical dynamics and to do so across a broad range of model complexity from nutrient-phytoplankton-zooplankton-detritus (NPZD) models to state-of-the-art plankton functional types (PFTs) models with considerable ecological sophistication. This study is 
Table 2. Composition of the marine ecosystems represented in each candidate model along with the total number of biogeochemical tracers (including those detailed in Table 1).

\begin{tabular}{lcccccc}
\hline & HadOCC & Diat-HadOCC & MEDUSA-2 & PlankTOM6 & PlankTOM10 & ERSEM \\
\hline $\begin{array}{l}\text { Generic phytoplankton } \\
\text { Diatoms }\end{array}$ & $\sqrt{ }$ & $\sqrt{ }$ & & $\sqrt{ }$ & $\sqrt{ }$ & \\
Large phytoplankton & & $\sqrt{ }$ & $\sqrt{ }$ & $\sqrt{ }$ & $\sqrt{ }$ & $\sqrt{ }$ \\
$\begin{array}{l}\text { Picophytoplankton } \\
\text { Coccolithophores }\end{array}$ & & & $\sqrt{ }$ & & $\sqrt{ }$ & $\sqrt{ }$ \\
$\mathrm{N}_{2}$ fixers & & & & $\sqrt{ }$ & $\sqrt{ }$ & \\
$\begin{array}{l}\text { Flagellates } \\
\text { Phaeocystis }\end{array}$ & & & & & & $\sqrt{ }$ \\
Generic zooplankton & $\sqrt{ }$ & $\sqrt{ }$ & & & $\sqrt{ }$ & \\
$\begin{array}{l}\text { Microzooplankton } \\
\text { Mesozooplankton }\end{array}$ & & & $\sqrt{ }$ & $\sqrt{ }$ & $\sqrt{ }$ & $\sqrt{ }$ \\
$\begin{array}{l}\text { Macrozooplankton } \\
\text { Heterotrophic nanoflagellates }\end{array}$ & & & & & $\sqrt{ }$ & $\sqrt{ }$ \\
Picoheterotrophs & & & & $\sqrt{ }$ & $\sqrt{ }$ & $\sqrt{ }$ \\
Tracers & 7 & 13 & 15 & 25 & 39 & 57 \\
\hline
\end{tabular}

still constrained by the use of a single ocean circulation and by a bespoke gradation of model complexity (PlankTOM6 and PlankTOM10 partially inform this). Nonetheless, this study represents an intercomparison along separate lines to those previously conducted.

\section{Method}

\subsection{Experimental design}

All participating models made use of a common version (v3.2) of the Nucleus for European Modelling of the Ocean (NEMO) physical ocean general circulation model (Madec, 2008) coupled to the Los Alamos sea-ice model (CICE) (Hunke and Lipscomb, 2008). This physical framework is configured at approximately $1^{\circ} \times 1^{\circ}$ horizontal resolution (ORCA100; $292 \times 362$ grid points), with a focusing of resolution around the equator to improve the representation of equatorial upwelling. Vertical space is divided into 75 fixed levels, which increase in thickness with depth from approximately $1 \mathrm{~m}$ at the surface to more than $200 \mathrm{~m}$ at $6000 \mathrm{~m}$. Partial level thicknesses are used in the specification of seafloor topography to improve the representation of deep water circulation. Vertical mixing is parameterized using the turbulent kinetic energy scheme of Gaspar et al. (1990), with modifications made by Madec (2008). To ensure that the simulations were performed by the different modelling groups using an identical physical run, a flexible configuration management (FCM) branch of this version of NEMO was created, and all biogeochemical models were implemented in parallel within this branch and run separately.

Simulations were initialised at the year 1890 from an extant physics-only spin-up (ocean and sea-ice) to minimise undesirable transient behaviour in ocean circulation. In terms of ocean biogeochemistry, all model runs made use of a common data set of three-dimensional fields for the initialisation of major tracers. Nutrients (nitrogen, silicon and phosphorus) and dissolved oxygen in this data set were drawn from the World Ocean Atlas 2009 (Garcia et al., 2010a, b), while dissolved inorganic carbon (DIC) and alkalinity were drawn from the Global Ocean Data Analysis Project (GLODAP) (Key et al., 2004). GLODAP does not include a DIC field that is directly valid for 1890 , so a temporally interpolated field was produced based on GLODAP's "pre-industrial" (i.e. 1800) and "1990s" fields of DIC. As there is currently no comprehensive spatial data set of the micronutrient iron, participating models were permitted to make use of different initial distributions of iron (typically those routinely used by the models in other settings). All other biogeochemical fields (e.g. plankton, particulate or dissolved organic material) were initialised to arbitrarily small initial conditions.

After initialisation at the year 1890, the models were run for 60 years (1890-1949 inclusive) under the so-called "normal year" of version 2 forcing for common ocean-ice reference experiments (CORE2-NYF; Large and Yeager, 2009). Subsequently, the models were run under transient interannual forcing from the same data set (CORE2-IAF) for a further 58 years (1950-2007 inclusive). CORE2 provides observationally derived geographical fields of downwelling radiation (separate long and short wave), precipitation (separate rain and snow) and surface atmospheric properties (temperature, specific humidity and winds) and is used in conjunction with bulk formulae to calculate net heat, freshwater and momentum exchange between the atmosphere and the ocean.

For all models, some degree of tuning occurred prior to this study, albeit in different physical frameworks (to varying degrees) to those used here. Tuning during this study was limited or absent between models, but some models, such 

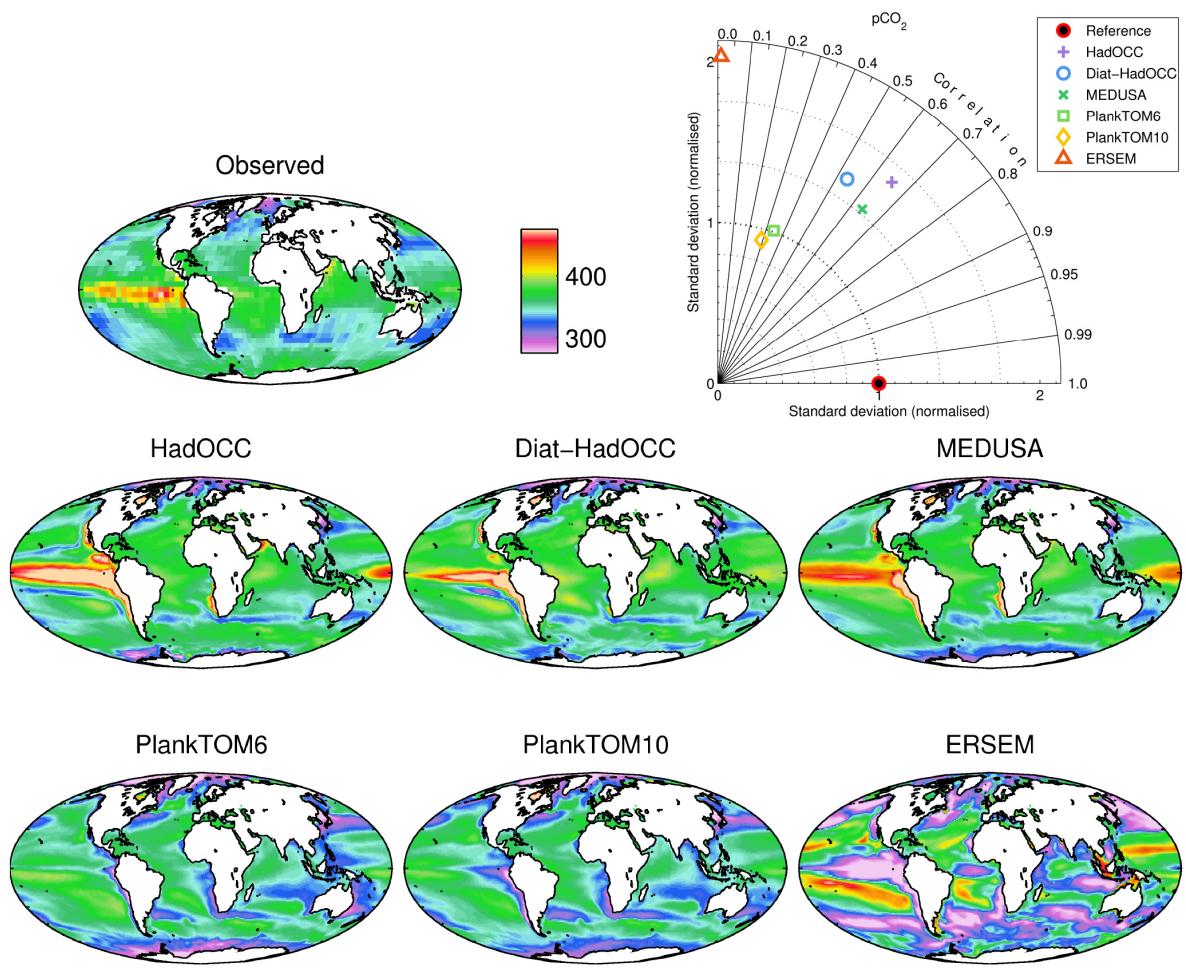

Figure 1. Observational (Takahashi et al., 2009; top left) and modelled annual average surface ocean $p \mathrm{CO}_{2}$ ( $\mu$ atm) for the year 2000. Mean field values: observations 357.7; HadOCC 368.8; Diat-HadOCC 369.2; MEDUSA 368.5; PlankTOM6 349.8; PlankTOM10 349.5; ERSEM 343.0.
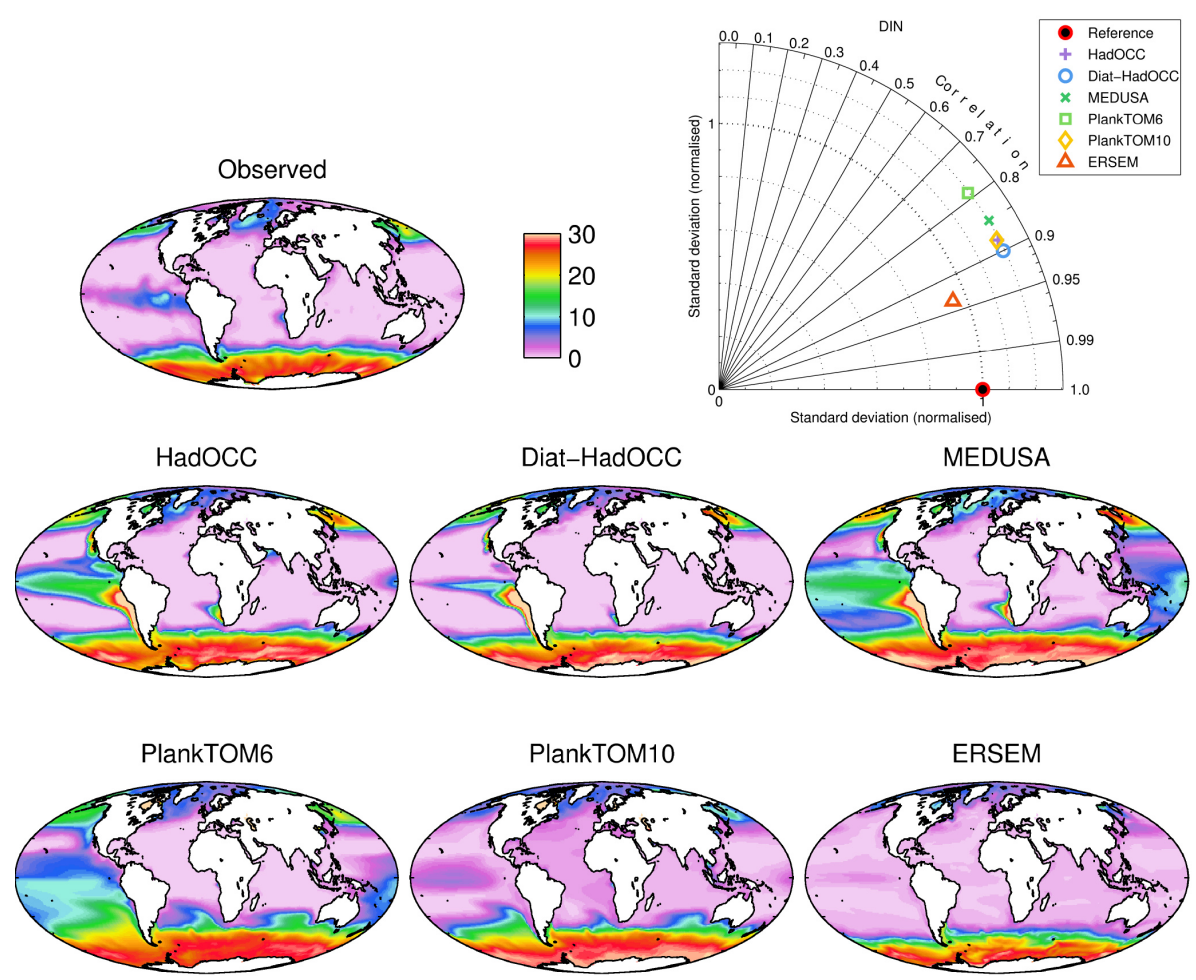

Figure 2. Observational (World Ocean Atlas, 2009; top left) and modelled annual average surface ocean dissolved inorganic nitrogen $\left(\mathrm{mmol} \mathrm{m}^{-3}\right)$ for the period 2000-2004. Mean field values: observations 5.24; HadOCC 7.88; Diat-HadOCC 6.33; MEDUSA 10.18; PlankTOM6 9.45; PlankTOM10 7.25; ERSEM 4.58. 

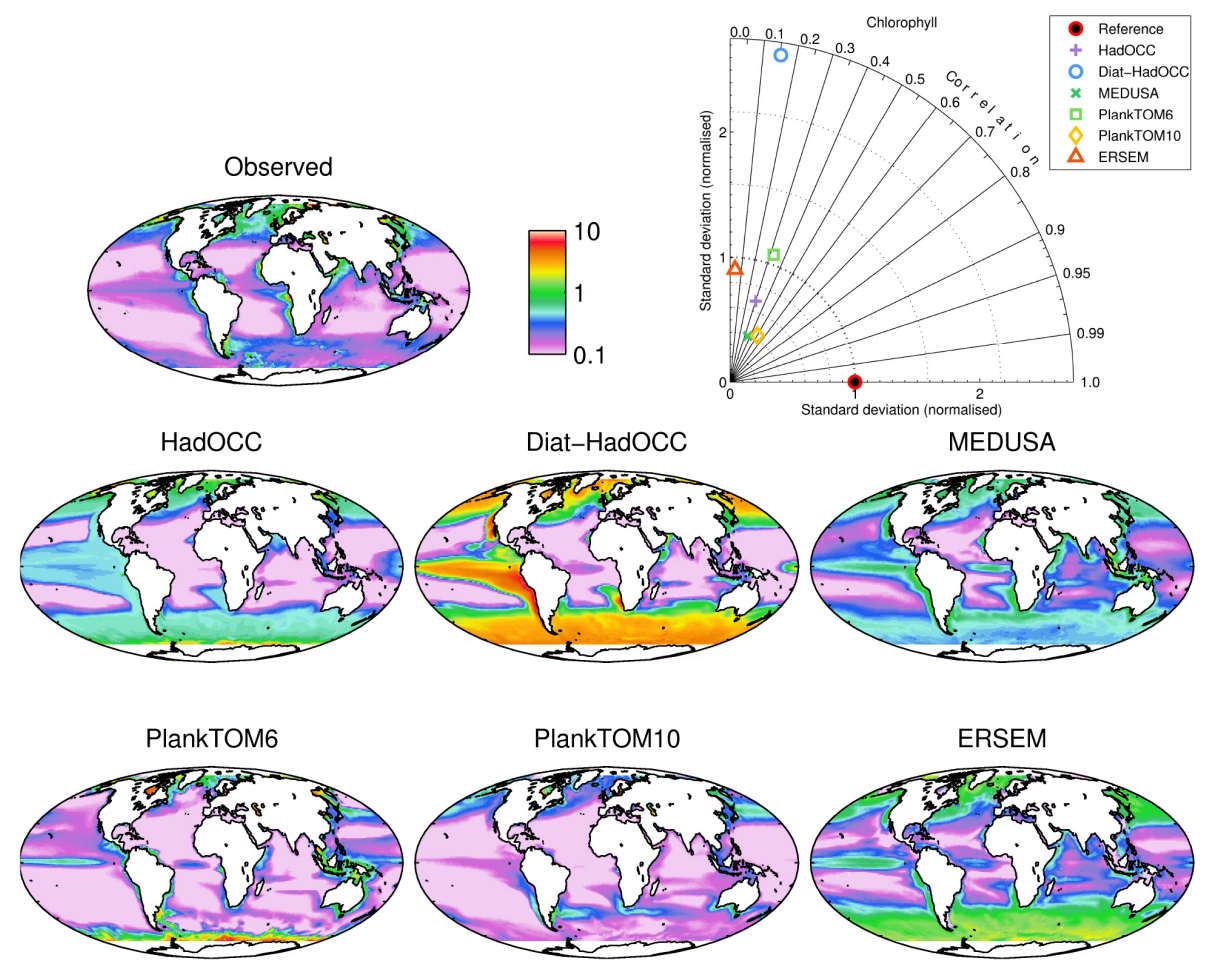

Figure 3. Observational (SeaWiFS; top left) and modelled annual average surface ocean chlorophyll (mg $\mathrm{m}^{-3}$ ) for the period 2000-2004. To avoid biasing the plots, observational data and model output are only shown for regions in which all months were represented at least once across all of the sampled years. Mean field values: observations 0.215; HadOCC 0.347; Diat-HadOCC 1.170; MEDUSA 0.346; PlankTOM6 0.312; PlankTOM10 0.160; ERSEM 0.501.

as HadOCC and MEDUSA, may have benefited from being previously tuned within the NEMO framework (although in a different version and grid configuration).

Figure S7 in the Supplement shows an intercomparison of the common NEMO physics with observations (temperature, Locarnini et al., 2010; salinity, Antonov et al., 2010; mixed layer depth, Monterey and Levitus, 1997) for several key physical fields. In terms of SST, NEMO represents observed patterns well despite simulating a warmer Gulf Stream and noticeably cooler temperatures in the vicinity of the Labrador Sea. In conjunction with fresher salinities in the north Atlantic (results not shown), these differences result in shallower depths of the mixed layer and pycnocline in this region. In contrast, in the Southern Ocean both mixed layer depths and the modelled pycnocline are markedly deeper than in observations. This latter regional bias has biogeochemical consequences across all of the models examined here (see later).

\subsection{Candidate model structures}

The models evaluated within this study vary significantly in biological complexity. The key features of the participating models are summarised below.

\subsubsection{HadOCC (Palmer and Totterdell, 2001)}

The Hadley Centre ocean carbon cycle model (HadOCC) model is a simple NPZD representation that uses N nutrient as its base currency but with coupled flows of C, alkalinity and $\mathrm{O}_{2}$. The model was the ocean biogeochemistry component of the UK Met Office's HadCM3 climate model and was used for the first-ever fully coupled carbon-climate study (Cox et al., 2000).

\subsubsection{Diat-HadOCC (Halloran et al., 2010)}

The Diat-HadOCC model is a development of the HadOCC model that includes two phytoplankton classes (diatoms and "other phytoplankton") and representations of the $\mathrm{Si}$ and Fe cycles, as well as a dimethyl sulphide (DMS) submodel. The model is the ocean biogeochemistry component of HadGEM2-ES (Collins et al., 2011), the UK Met Office's Earth system model used to run simulations for CMIP5 and the Intergovernmental Panel on Climate Change (IPCC) fifth assessment report (AR5).

\subsubsection{MEDUSA-2 (Yool et al., 2011, 2013)}

The model of Ecosystem Dynamics, nutrient Utilisation, Sequestration and Acidification (MEDUSA) is 
an "intermediate complexity" plankton ecosystem model designed to incorporate sufficient complexity to address key feedbacks between anthropogenically driven changes (climate, acidification) and oceanic biogeochemistry. MEDUSA-2 resolves a size-structured ecosystem of small (nanophytoplankton and microzooplankton) and large (microphytoplankton and mesozooplankton) components that explicitly includes the biogeochemical cycles of $\mathrm{N}, \mathrm{Si}$ and Fe nutrients as well as the cycles of $\mathrm{C}$, alkalinity and $\mathrm{O}_{2}$. As such, MEDUSA-2 is broadly similar in structure to Diat-HadOCC but includes several more recent parameterisations.

\subsubsection{PlankTOM6 and PlankTOM10 (Le Quéré et al., 2005)}

PlankTOM is a dynamic green ocean model that represents lower-trophic level marine ecosystems based on PFTs. A hierarchy of PlankTOM models exists that vary in the number of PFTs resolved. Two members drawn from this stable were used in this study. PlankTOM6 includes six PFTs - diatoms, coccolithophores, mixed phytoplankton, bacteria, protozooplankton and mesozooplankton - while PlankTOM10 includes an additional four PFTs - nitrogen fixers, Phaeocystis, picophytoplankton and macrozooplankton (Le Quéré et al. 2005; Buitenhuis et al., 2013). The models include the marine cycles of $\mathrm{C}, \mathrm{N}, \mathrm{O}_{2}, \mathrm{P}, \mathrm{Si}$, a simplified $\mathrm{Fe}$ cycle and three types of detrital organic pools, including their ballasting properties and estimates of the air-sea fluxes of $\mathrm{CO}_{2}, \mathrm{O}_{2}$, DMS and $\mathrm{N}_{2} \mathrm{O}$. PlankTOM6 and PlankTOM10 were developed by an international community of ecologists and modellers to quantify the interactions between climate and marine biogeochemistry, particularly those mediated through $\mathrm{CO}_{2}$. They make use of extensive synthesis of data for the parameterisation of growth rates of PFTs (e.g. Buitenhuis et al., 2006, 2010) and for the model evaluation (Buitenhuis et al., 2013).

\subsubsection{ERSEM (Baretta et al., 1995; Blackford et al., 2004)}

European regional seas ecosystem model (ERSEM) is a generic lower-trophic level model designed to represent the biogeochemical cycling of $\mathrm{C}$ and nutrients as an emergent property of ecosystem interaction. The ecosystem is subdivided into three functional types - producers (phytoplankton), decomposers (bacteria) and consumers (zooplankton) - and then further subdivided by trait - size and silica uptake - to create a food web. Physiological (ingestion, respiration, excretion and egestion) and population (growth, migration and mortality) processes are included in the descriptions of functional group dynamics. Four phytoplankton (picophytoplankton, nanophytoplankton, diatoms and non-siliceous macrophytoplankton), three zooplankton (microzooplankton, heterotrophic nanoflagellates and mesozooplankton) and one bacterium are represented, along with the cycling of $\mathrm{C}$, $\mathrm{N}, \mathrm{P}, \mathrm{Si}$ and $\mathrm{O}_{2}$ through pelagic (Blackford et al., 2004) and benthic (Blackford, 1997) ecosystems. ERSEM, used for shelf sea water quality monitoring and climate impact assessment, has been coupled to fisheries models (e.g. Barange et al., 2014) and is run operationally by the UK Met Office (e.g. Siddorn et al., 2007).

The intercomparison process required limited changes to model organisation and code, and models retained disparate parameterisations for several overlapping processes, including ocean carbonate chemistry and air-sea exchange (HadOCC, Diat-HadOCC - Dickson and Goyet, 1994; Nightingale et al., 2000; MEDUSA - Blackford and Gilbert, 2007; PlankTOM-6, PlankTOM-10 - Edmond and Gieskes, 1970, Broecker et al., 1982, Wanninkhof, 1992; ERSEM - Artoli et al., 2012). In the case of calcium carbonate $\left(\mathrm{CaCO}_{3}\right)$ production, the models utilised a range of different parameterisations. HadOCC and Diat-HadOCC use a simple empirical relationship that ties $\mathrm{CaCO}_{3}$ production to primary production. MEDUSA relates $\mathrm{CaCO}_{3}$ production to export production with a PIC: POC ratio (particulate inorganic carbon : particulate organic carbon ratio) dependent on calcite saturation state. In PlankTOM-6 and PlankTOM-10, coccolithophore algae are explicitly modelled with a fixed PIC : POC ratio. ERSEM relates $\mathrm{CaCO}_{3}$ production to export production driven by nanophytoplankton losses with a variable PIC : POC ratio dependent on temperature, nutrient limitation and calcite saturation state. Meanwhile, $\mathrm{CaCO}_{3}$ dissolution was a simple exponential function of depth in the HadOCC models, with the other models modifying similar vertical dissolution with reference to the ambient saturation state of $\mathrm{CaCO}_{3}$.

The representation of biogeochemical cycles and biota in each model is summarised in Tables 1 and 2 respectively.

\subsection{Model evaluation}

Assessment against observational data sets was made for a set of bulk ocean biogeochemical properties that were common across all models: $p \mathrm{CO}_{2}$, alkalinity, DIC, dissolved inorganic nitrogen (DIN), chlorophyll and primary production. In all cases, model results were regridded to the same geographical grid (World Ocean Atlas) and guided by literature on appropriate skill metrics (e.g. Doney et al., 2009; Stow et al., 2009). Model skill was assessed through statistical techniques such as global surface field standard deviation and spatial pattern correlation coefficients. In the biogeochemical regions of the north Atlantic, equatorial Pacific and Southern Ocean, depth profiles of model outputs were also assessed against observations within the top $1000 \mathrm{~m}$ of the water column.

Observational fields used within the model intercomparison are comprised of World Ocean Atlas 2009 DIN (Garcia et al., 2010a), chlorophyll (O'Reilly et al., 1998) and $p \mathrm{CO}_{2}$ (Takahashi et al., 2009). Because of its 

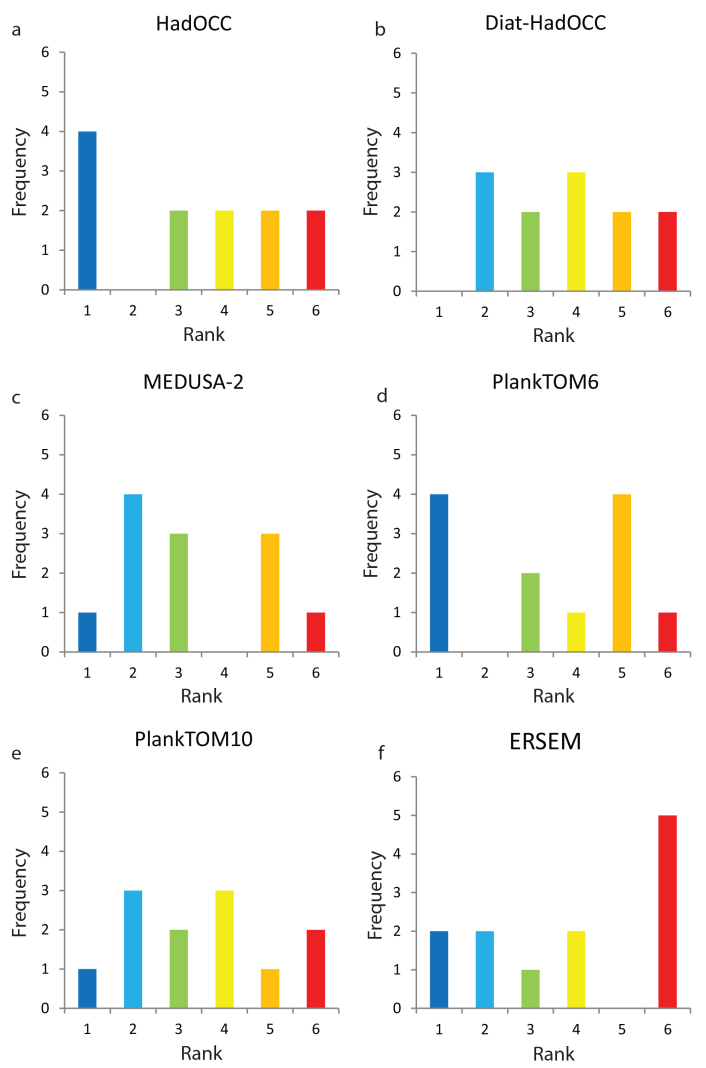

Figure 4. Frequency distributions of best to worst performances for each model in terms of correlation coefficients and normalised standard deviations of annual surface fields and depth integrated primary productivity.

biogeochemicalimportance and the diversity in published estimates, observational primary production is an average of three empirical models - Behrenfeld and Falkowski (1997), Carr et al. (2006) and Westberry et al. (2008) - which are all estimates derived from satellite ocean colour and SST. The observational fields of chlorophyll and primary production used here represent averages over the 2000-2004 time period. This same period is used throughout the following analysis as a standard interval except in the case of DIC and alkalinity, which are analysed over the mean 1990-1999 period corresponding to the GLODAP data product.

These fields were selected for several reasons. Firstly, they are ocean or biogeochemical bulk properties for which there are global-scale observations. Secondly, these fields broadly represent foundational aspects of marine biogeochemical cycles. For instance, nutrients play a critical role in regulating the distribution and occurrence of marine plankton, while phytoplankton photosynthesis represents the vast majority of the primary energy source to marine ecosystems. Thirdly, the measurement of these fields is relatively well defined with long-established standard methodologies. Properties that are directly related to biological entities, for instance biomass abundances, can be less precisely defined, difficult to match up with modelled quantities or even absent from some models examined here. That said, the observational field of global-scale primary production used here has a relatively high uncertainty because it is drawn from three methodologies that exhibit a large range (cf. Yool et al., 2013). Finally, the examined properties are those which, if modelled poorly, legitimately cast doubt over the wider utility of a biogeochemical model in an Earth systems context. Model results always depart from observations, but systematic disagreement with these basic observations is strongly suggestive of problems with process representation within a model. The model comparison focuses on the mean and seasonal cycle. It does not include evaluation of variability over interannual or longer timescales, in part because of limited data availability.

\section{Results}

\subsection{Model skill assessment}

\subsubsection{Surface fields}

Figures 1-3 (and Figs. S1-S3 in the Supplement) show annual average fields from each of the models for a series of ocean properties together with comparable observational fields. The figures also include a panel that shows the corresponding model-observation Taylor diagram (Taylor, 2001). These illustrate both the correlation between (azimuthal position) and relative variability of (radial axis) of model and observations, such that models more congruent with observations generally appear closer to the reference marker on the $x$ axis of the diagram. As Taylor diagrams do not account for mean field biases (Joliff et al., 2009), these are provided separately in figure legends.

Figure 1 shows annual average surface $p \mathrm{CO}_{2}$ fields for both models and observations, with correlation coefficients ranging from $r=0.01$ to $r=0.68$ (Takahashi et al., 2009). In general, the simpler models (HadOCC, Diat-HadOCC and MEDUSA-2) better capture the global spatial pattern of $p \mathrm{CO}_{2}(r=0.54$ to $r=0.68)$, but they overestimate the standard deviation in global surface $p \mathrm{CO}_{2}$ up to a factor of 2. This overestimation of the variance in global surface $\mathrm{pCO}_{2}$ is a result of high-modelled $p \mathrm{CO}_{2}$ values in the equatorial Pacific and in particular the eastern equatorial Pacific. In contrast, the more complex models (PlankTOM6, PlankTOM10 and ERSEM) perform considerably worse in terms of capturing global spatial patterns of surface ocean $p \mathrm{CO}_{2}$. In particular, all three models underestimate the observed high $p \mathrm{CO}_{2}$ values along the equatorial Pacific ocean as well as the high coastal $p \mathrm{CO}_{2}$ values in that region, opposite to the bias found in simpler models. However, the PlankTOM models overall show comparable standard deviations in mean global surface $p \mathrm{CO}_{2}$ to those seen in observations. 
Table 3. Model-observation correlation coefficients $(R)$ and standard deviations normalised by the standard deviation of observations $(\sigma)$ for all examined annual surface fields and depth-integrated primary productivity.

\begin{tabular}{|c|c|c|c|c|c|c|c|c|c|c|c|c|}
\hline \multirow[t]{2}{*}{ Model } & \multicolumn{2}{|c|}{$p \mathrm{CO}_{2}$} & \multicolumn{2}{|c|}{ DIN } & \multicolumn{2}{|c|}{ Chl. } & \multicolumn{2}{|c|}{ Alkalinity } & \multicolumn{2}{|c|}{ DIC } & \multicolumn{2}{|c|}{$\begin{array}{c}\text { Primary } \\
\text { production }\end{array}$} \\
\hline & $R$ & $\sigma$ & $R$ & $\sigma$ & $R$ & $\sigma$ & $R$ & $\sigma$ & $R$ & $\sigma$ & $R$ & $\sigma$ \\
\hline HadOCC & 0.68 & 1.92 & 0.88 & 1.20 & 0.30 & 0.68 & 0.91 & 1.19 & 0.93 & 1.18 & 0.19 & 0.92 \\
\hline Diat-HadOCC & 0.54 & 1.77 & 0.90 & 1.20 & 0.15 & 2.65 & 0.91 & 1.19 & 0.93 & 1.13 & 0.13 & 1.51 \\
\hline MEDUSA-2 & 0.64 & 1.56 & 0.85 & 1.21 & 0.36 & 0.40 & 0.88 & 1.14 & 0.92 & 1.17 & 0.64 & 1.10 \\
\hline PlankTOM6 & 0.34 & 1.03 & 0.79 & 1.20 & 0.32 & 1.08 & 0.70 & 0.88 & 0.75 & 0.96 & 0.47 & 0.61 \\
\hline PlankTOM10 & 0.29 & 0.94 & 0.88 & 1.19 & 0.50 & 0.43 & 0.58 & 1.16 & 0.65 & 1.08 & 0.53 & 0.74 \\
\hline ERSEM & 0.01 & 2.04 & 0.94 & 0.95 & 0.04 & 0.91 & 0.84 & 1.18 & 0.86 & 1.07 & -0.08 & 1.12 \\
\hline Range & 0.67 & 1.09 & 0.15 & 0.26 & 0.46 & 2.25 & 0.33 & 0.31 & 0.28 & 0.23 & 0.72 & 0.90 \\
\hline
\end{tabular}

The negative $p \mathrm{CO}_{2}$ biases in the equatorial Pacific exhibited by the PlankTOM6, PlankTOM10 and ERSEM models may be explained, at least in part, by the positive biases that these models show for surface alkalinity in this region (Fig. S3). The models with positive $p \mathrm{CO}_{2}$ biases in the equatorial Pacific (HadOCC, Diat-HadOCC and MEDUSA-2) do not have negative surface alkalinity biases in this region, but values are much closer to observations (Fig. S3). The root of these alkalinity biases lies in variation in PIC production by the models in this region as discussed in greater detail below.

Figure 2 illustrates model performance of annual average surface dissolved inorganic nitrogen (DIN) concentrations. Here, all models capture global patterns relatively well, with correlation coefficients $>0.8$, in part because of the initialisation from observations in 1890. The model with the highest spatial pattern correlation coefficient is ERSEM, although it slightly underestimates the global variability of DIN. The other models have lower spatial pattern correlation coefficients and generally overestimate the global variability of DIN. PlankTOM6 performs below other models, while PlankTOM10 has a similar performance to the simpler models. In general, aside from ERSEM and PlankTOM10, most models show elevated Pacific DIN, and the simpler models, MEDUSA-2 in particular, exhibit high equatorial anomalies. Finally, while ERSEM shows good agreement throughout most of the world ocean, both the north Atlantic and north Pacific show anomalously low annual average DIN concentrations.

Surface DIN concentrations are influenced by both the efficiency of primary production and the efficiency of remineralization, both of which differ between models. Although we do not explore the differences in remineralization, the models which show positive DIN biases in the equatorial Pacific (HadOCC, Diat-HadOCC and MEDUSA-2) are generally shown to also have positive integrated primary production biases in this region (Fig. S1). To a lesser extent, the reverse is true of the models with negative DIN biases in the equatorial Pacific (PlankTOM10 and ERSEM).
Figure 3 shows low correlation $(r<0.5)$ for annual surface chlorophyll concentrations for all models. The models with the highest correlation coefficients are PlankTOM10 (0.49) followed by MEDUSA-2 (0.36). All other models have correlation coefficients $<0.2$. Anomalously high chlorophyll values in the equatorial Pacific and especially the Southern Ocean significantly elevate the spatial variability of DiatHadOCC above that of observations (and all other models). More generally, with the exception of PlankTOM10, all of the models show some degree of excess chlorophyll in the Southern Ocean, with Diat-HadOCC exhibiting very high concentrations in this relatively unproductive region.

In addition to the ocean properties shown in Figs. 13 , complementary figures for alkalinity, DIC and primary production can be found in the supplementary material (Figs. S1-S3). In each case, global annual average fields are shown together with the corresponding Taylor diagram.

Table 3 shows the correlation coefficients and standard deviations normalised relative to observations of the models for all six of the ocean properties (five surface fields plus depthintegrated primary production). The range of correlation coefficients over all of the models is shown for each field. As already suggested above, model performance varies both between fields and between models. All models perform consistently and relatively well for DIN and DIC in part because of the "memory" of initial distributions. Model performance varies more widely for $p \mathrm{CO}_{2}$ and primary production and varies most widely for chlorophyll, although it is consistently poor across all models.

Figure 4 summarises the data in Table 3 by showing the distribution of performance rankings (both correlation coefficients and normalised standard deviations) across the selected fields for each model, i.e. the number of first, second, etc. rankings for each model. No model is shown to consistently outperform all other models across all metrics. Indeed, all models perform best in at least one metric, and similarly all models perform worst in at least one metric. There is little discernable relationship between model complexity and model performance. Indeed, Table 3 shows that for four out 

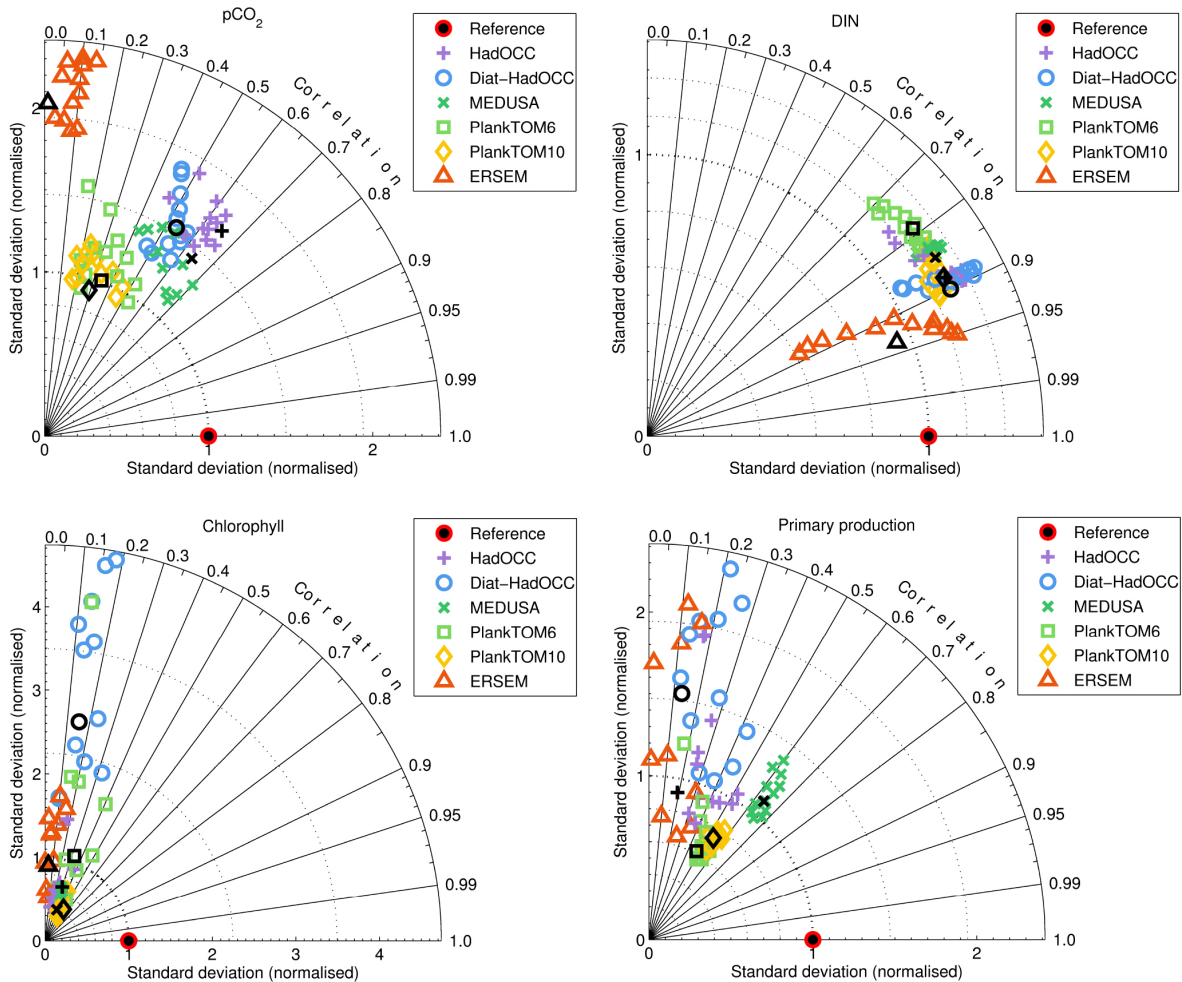

Figure 5. Monthly Taylor plots for $p \mathrm{CO}_{2}$, dissolved inorganic nitrogen (DIN), chlorophyll and primary production for all models relative to observations. Annual averages are shown in black. Note that negative correlation coefficients are not shown in the Taylor plot.

of six fields the best performing model in terms of correlation coefficients is a simpler model (i.e. HadOCC, Diat-HadOCC or MEDUSA-2) and for five out of six fields the best performing model in terms of normalised standard deviations is a more complex model (i.e. PlankTOM6, PlankTOM10 or ERSEM).

These findings in annual average model performance are found to be consistent when examined at monthly timescales (Fig. 5).

\subsubsection{Depth profiles}

While the majority of biological activity in the ocean is concentrated in its surface layers, biogeochemical fields in the deep ocean have a complex structure created through the interaction of ocean physics with biologically mediated processes such as export and remineralization. As such, model performance cannot be solely assessed from surface fields of ocean BGC properties. To examine this, Figs. 6 and 7 show the annual average depth profiles of DIC and alkalinity for three important regions: the north Atlantic (Atlantic $\left.0-60^{\circ} \mathrm{N}\right)$, Southern Ocean $\left(\geq 60^{\circ} \mathrm{S}\right)$ and equatorial Pacific (Pacific Ocean $15^{\circ} \mathrm{S}-15^{\circ} \mathrm{N}$ ).

In Fig. 6, all models are shown to capture the DIC profile in the equatorial Pacific, though HadOCC, Diat-HadOCC and MEDUSA-2 are somewhat closer to observations than
ERSEM and the PlankTOM models. A similar situation is seen in the north Atlantic where the depth profiles of MEDUSA-2, HadOCC and Diat-HadOCC are closest to observations, although surface agreement is greater than that at depth. All models are shown to perform relatively poorly in the Southern Ocean, with much weaker gradients with depth than observations. HadOCC, Diat-HadOCC and ERSEM show gradients that are marginally closer to those observed, but all of the models consistently fail to reproduce the observed $>100 \mathrm{mmol} \mathrm{m}^{-3}$ surface- $1000 \mathrm{~m}$ increase. As Fig. S7 in the Supplement shows, this common problem of vertical homogeneity between the models is driven by systematic biases in vertical mixing in this region as well as known errors in ocean circulation (e.g. Yool et al., 2013).

The annual average depth profiles of alkalinity are shown in Fig. 7. In the north Atlantic, HadOCC and Diat-HadOCC are closer to observations while ERSEM and, particularly, MEDUSA-2 are further away from observations (but in opposite directions). Again, and for the same reasons as outlined above, no model performs well at capturing the depth profile observed in the Southern Ocean. In the equatorial Pacific, all of the models have similar alkalinity at depth but diverge from observations towards the surface. The near-surface depth profiles in HadOCC, DiatHadOCC and MEDUSA-2 are closest to observations in that region. Alkalinity shows very little variability with 

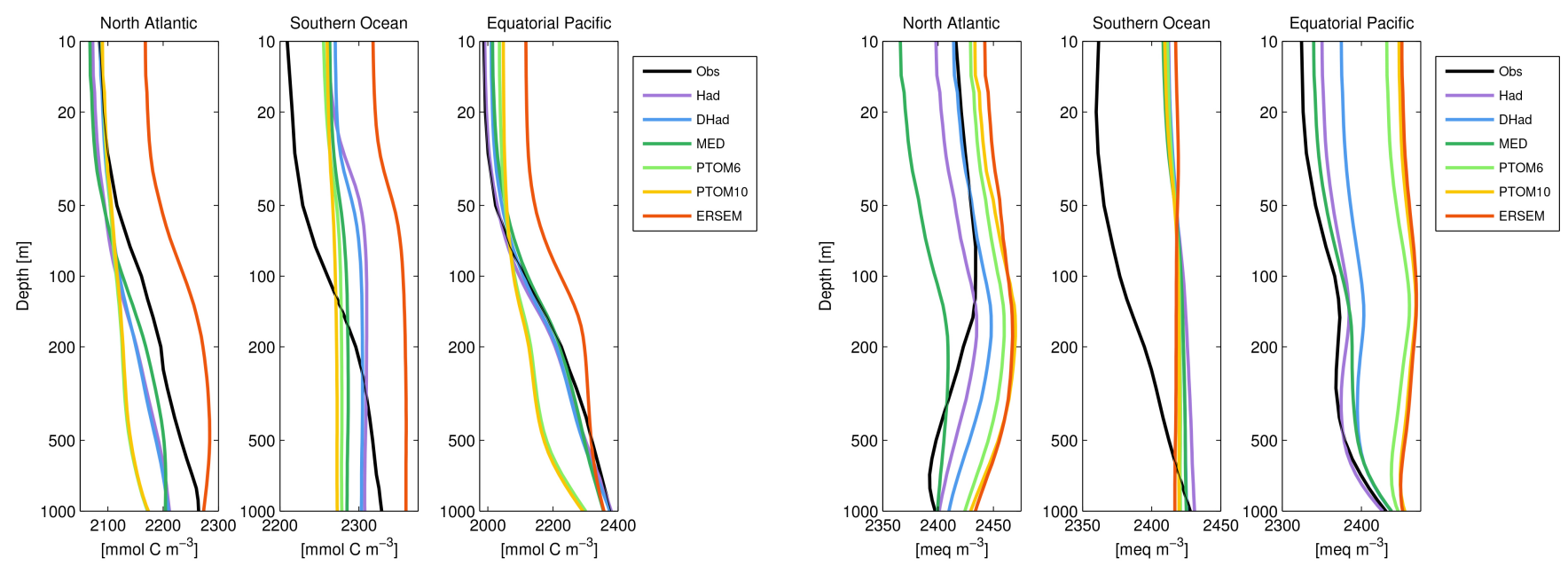

Figure 6. Observed (black; GLODAP) and modelled profiles of dissolved inorganic carbon $\left(\mathrm{mmol} \mathrm{C} \mathrm{m}{ }^{-3}\right)$ in the north Atlantic (0 to $\left.60^{\circ} \mathrm{N}\right)$, Southern Ocean $\left(90\right.$ to $\left.60^{\circ} \mathrm{S}\right)$ and equatorial Pacific $\left(15^{\circ} \mathrm{S}\right.$ to $\left.15^{\circ} \mathrm{N}\right)$. Vertical scaling is logarithmic $\left(\log _{10}\right)$.

depth in the PlankTOM6, PlankTOM10 and ERSEM models and is higher than observations in near-surface waters $\left(>100 \mathrm{meq}^{-3}\right)$. This excess alkalinity may explain the broadly lower $p \mathrm{CO}_{2}$ values visible in this region in Fig. 1. The source of this bias in surface alkalinity is, at least in part, due to disparity in modelled $\mathrm{CaCO}_{3}$ production in this region. As Figs. S8-S10 in the Supplement show, PlankTOM6, PlankTOM10 and ERSEM export negligible particulate inorganic carbon (PIC; Fig. S9) relative to particulate organic carbon (POC; Fig. S8) in this region. This results in low rain ratios (Fig. S10) and the divergence of DIC and alkalinity performance of these models in this region. The lack of PIC export in these models runs contrary to observations (e.g. Dunne et al., 2007) but reflects the current difficulty in modelling $\mathrm{CaCO}_{3}$ production - which HadOCC, Diat-HadOCC and MEDUSA-2 circumvent by simplistic empirical parameterisations.

The depth profiles of DIN and $\mathrm{O}_{2}$ are given in the Supplement (Figs. S4-5).

\subsection{Computational benchmarking}

Computational timing tests (CPU time) were carried out relative to the ocean component of the HadGEM3 (Hewitt et al., 2011) model (ORCA1.0L75), on standard configurations of 128 and 256 processors on an IBM Power7 machine. As would be intuitively expected, the cost of candidate ocean biogeochemical models is found to be higher for models with more tracers regardless of the number of processors used. While there are deviations in both directions between the models, there is a broadly linear relationship between number of model tracers and compute cost (Fig. S6 in the Supplement), reflecting the significant cost of applying advection and mixing terms to each tracer.

Figure 7. Observed (black; GLODAP) and modelled profiles of alkalinity $\left(\mathrm{meq} \mathrm{m}^{-3}\right)$ in the north Atlantic $\left(0\right.$ to $\left.60^{\circ} \mathrm{N}\right)$, Southern Ocean $\left(90\right.$ to $\left.60^{\circ} \mathrm{S}\right)$ and equatorial Pacific $\left(15^{\circ} \mathrm{S}\right.$ to $\left.15^{\circ} \mathrm{N}\right)$. Vertical scaling is logarithmic $\left(\log _{10}\right)$.

Using ERSEM (the computationally most expensive model) increases computational cost approximately 6-fold relative to HadOCC when 128 processors are used. This relative increase in computational cost is reduced to approximately 4.5 -fold when 256 processors are used. PlankTOM10 has the greatest relative reduction $(36.6 \%)$ in computational cost when run on 256 processors as opposed to 128 , although this model would still increase the total cost of the ocean component by a factor of 5 relative to a physics-only ocean, compared to a factor of 1.5 for HadOCC (Table 4).

\section{Discussion}

Our model comparison suggests that for global annual average surface fields, global monthly average surface fields and annual average depth profiles in three oceanographic regions, there is little evidence that increasing the complexity of OBGC models leads to improvements in the representation of large-scale ocean patterns of bulk properties. In some cases, the comparison suggests that simpler OBGC are closer to observations than intermediate or complex models for the standard assessment metrics used here.

The biologically simpler models HadOCC, Diat-HadOCC and MEDUSA-2 are shown to have generally higher global spatial pattern correlation coefficients of $p \mathrm{CO}_{2}$, DIC and alkalinity at both annual and monthly temporal resolution (Figs. 1, 5 and Table 3). The more complex models PlankTOM6, PlankTOM10 and, in the case of DIC, ERSEM have annual and monthly standard deviations that are generally closer to observations than the simplest two models (HadOCC and Diat-HadOCC). As such, we find no robust relationship between model complexity and model skill at capturing global-scale distributions of surface $p \mathrm{CO}_{2}$, DIC 
Table 4. Computational cost of each candidate model when coupled to the ocean component of HadGEM3, relative to a physics-only simulation with the same ocean model (ORCA1.0L75). A cost of 2 indicates that adding the biogeochemistry model doubles total simulation cost. Timings are shown for simulations carried out on 128 and 256 processors of an IBM Power7 machine.

\begin{tabular}{lcc}
\hline Model & $\begin{array}{c}\text { Cost } \\
\text { (128 processors) }\end{array}$ & $\begin{array}{c}\text { Cost } \\
\text { (256 processors) }\end{array}$ \\
\hline HadOCC & 1.75 & 1.48 \\
Diat-HadOCC & 2.36 & 1.88 \\
MEDUSA-2 & 2.73 & 2.10 \\
PlankTOM6 & 5.11 & 3.52 \\
PlankTOM10 & 7.74 & 4.90 \\
ERSEM & 10.36 & 6.87 \\
\hline
\end{tabular}

and alkalinity. The biologically simpler models are shown to generally best capture the depth profiles of DIC and alkalinity in the north Atlantic and equatorial Pacific (Figs. 6-7), possibly because their biological export production can more easily be tuned to maintain the observed vertical gradients.

There are, however, ocean biogeochemical fields where models of greater biological complexity tend to equate to improved model skill. The annual and monthly global correlation coefficients of the PlankTOM models are shown to be closest to observations for chlorophyll and primary production fields (Fig. 3 and Table 4). These PlankTOM models do not consistently produce the annual chlorophyll and primary production field standard deviations closest to observations (Table 4); however, at monthly resolution their field standard deviations are the most consistent across models (Fig. 5).

The comparison of depth profiles shows that despite all models being initialised from the same observational fields, there is quite a lot of divergence even at depths of less than $1000 \mathrm{~m}$. In some cases, such as alkalinity in the Southern Ocean (Fig. 7), all models have a similar systematic bias compared to observations. This is suggestive of the influence of errors within the physical ocean model. That is, the ocean biogeochemistry may be influenced to a greater extent by the physical ocean model and hence there is a common response across models. For other fields such as DIN in the Southern Ocean and equatorial Pacific (Fig. S5), models have both positive and negative biases compared to observations, suggestive of a greater relative role of the OBGC model than the physical model.

It is clear that more biologically complex models are required to more completely assess the impacts of environmental change on marine ecosystems. By representing processes that are not present in simpler models, the more complex models are also able to represent additional factors such as climatically active gases (e.g. DMS, $\mathrm{N}_{2} \mathrm{O}$ ). Assessment of such representations, however, fell outside the scope of this paper. Models of intermediate complexity (e.g. DiatHadOCC and MEDUSA-2) are shown in this intercompari- son to reproduce large-scale ocean biogeochemistry features relatively well, yet minimise computational cost and have sufficient biological complexity to allow important ESM questions to be explored, including those that require an explicit iron cycle (e.g. ocean iron fertilisation).

It should be noted that models implemented within the NEMO physical ocean framework prior to this intercomparison project had an advantage over those new to this framework. This is a somewhat unavoidable consequence of what is also one of this intercomparison study's main strengths, namely that the models were adapted to use the same ocean physics framework. Specifically, the HadOCC and MEDUSA-2 model developers were familiar with NEMO v3.2 and had some previous opportunity to tune models. Linked to this is the question of how dependent the results were on parameter values. Although model developers were afforded a limited opportunity to tune parameters, given further time to tune one would expect improved performance, especially for those models that had not been previously implemented within NEMO v3.2.

The rationale for the chosen fields of intercomparison was, as stated previously, that they are common across all models and are key facets of global marine biogeochemistry. It could, however, be argued that these bulk fields were insufficient to adequately assess all models and in particular the most complex models. Further analysis beyond the scope of this paper will be necessary to evaluate mechanistically the implications of the different biological components in each model.

Finally, although computational cost is discussed as a pragmatic driver of OBGC model selection, it should be noted that computer power is continuously increasing and the intercomparison results presented here may differ for an alternative spatial resolution ocean grid requiring greater computational resources. In addition, ongoing efforts to transport passive ocean tracers on degraded spatial scales (e.g. Levy et al., 2012) have the potential to result in computational savings that would realistically permit the implementation of higher complexity OBGC models within ESMs.

\section{Conclusions}

The six ocean biogeochemical models analysed within this intercomparison cover a large range of ecosystem complexity (from 7 tracers in HadOCC to 57 in ERSEM), and therefore result in a range of approximately five in computational costs (from increasing the cost of the physical ocean model by a factor of 2 to a factor of 10). Results suggest little evidence that higher biological complexity implies better model performance in reproducing observed global-scale bulk properties of ocean biogeochemistry.

As no model is found to have the highest skill across all metrics and all are most or least skilful for at least one metric, our results suggest that it is in the interest of the international 
climate modelling community to maintain a diverse suite of ocean biogeochemical models.

One priority for the next generation of Earth system models (CMIP6) is to enhance model resolution in the hope that it will resolve some of the existing biases in climate models. This puts pressure on the computing time available for representing biological complexity. Our results suggest that intermediate complexity models (such as MEDUSA-2 and Diat-HadOCC) offer a good compromise between the representation of biological complexity (through their inclusion of an iron cycle) and computer time given their relatively good performance in reproducing bulk properties. However, intermediate complexity models are limited in the detail to which they can address climate feedbacks, and it may be that more complex models can in future provide additional insight based on ongoing measurements and data syntheses.

The quest for increasing resolution in ESMs is unlikely to end soon, as the resolution needed to resolve eddies in the ocean $\left(1 / 8^{\circ}\right.$ or less) needs to be achieved before important improvements in representing climate dynamics are achieved. Most ESMs being developed for the next CMIP phase will have a grid of $1 / 2$ to $1 / 4^{\circ}$. Even with increasing computational power and schemes for accelerating transport of passive tracers (Levy et al., 2012) available, other priorities (e.g. ensemble simulations for risk assessments) may still make it difficult to prioritise the representation of biogeochemical complexity in ESMs. In order to achieve scientific progress on important questions of the interactions between marine biogeochemistry and climate, it is important that lower resolution ESMs that prioritise biogeochemical complexity are maintained and used in CMIP exercises in parallel- to higher-resolution models.

\section{The Supplement related to this article is available online at doi:10.5194/bg-11-7291-2014-supplement.}

Acknowledgements. This work was funded by the UK Natural Environmental Research Council Integrated Marine Biogeochemical Modelling Network to Support UK Earth System Research (i-MarNet) project (NE/K001345/1) and the UK Met Office. MFR was partially funded by the EC FP7 GreenSeas project.

Edited by: J. Middelburg

\section{References}

Antonov, J. I., Seidov, D., Boyer, T. P., Locarnini, R. A., Mishonov, A. V., Garcia, H. E., Baranova, O. K., Zweng, M. M., and Johnson, D. R.: World ocean atlas 2009, volume 2: Salinity, in: NOAA Atlas NESDIS 69, edited by: Levitus, S., US Government Printing Office, Washington, DC, USA, 184 pp., 2010.
Artioli, Y., Blackford, J. C., Butenschön, M., Holt, J. T., Wakelin, S. L., Thomas, H., Borges, A. V., and Allen, J. I.: The carbonate system in the north sea: Sensitivity and model validation, J. Mar. Syst., 102, 1-13, 2012

Barange, M., Merino, G., Blanchard, J. L., Scholtens, J., Harle, J., Allison, E. H., Allen, J. I., Holt, J., and Jennings, S.: Impacts of climate change on marine ecosystem production in societies dependent on fisheries, Nat. Clim. Change, 4, 211-216, doi:10.1038/NCLIMATE2119, 2014.

Baretta, J. W., Ebenhoh, W., and Ruardij, P.: The European Regional Seas Ecosystem Model, a complex marine ecosystem model, Neth. J. Sea Res. 33, 233-246, 1995.

Behrenfeld, M. J. and Falkowski, P. G.: Photosynthetic rates derived from satellite-based chlorophyll concentration, Limnol. Oceanogr., 42, 1-20, 1997.

Blackford, J. C.: An analysis of benthic biological dynamics in a North Sea ecosystem model, J. Sea Res., 38, 213-230, 1997.

Blackford, J. C. and Gilbert, F. J.: pH variability and $\mathrm{CO}_{2}$ induced acidification in the North Sea, J. Mar. Syst., 64, 229-241, 2007.

Blackford, J. C., Allen, J. I., and Gilbert, F. J.: Ecosystem dynamics at six contrasting sites: a generic modelling study, J. Mar. Syst., 52, 191-215, 2004.

Bopp, L., Resplandy, L., Orr, J. C., Doney, S. C., Dunne, J. P., Gehlen, M., Halloran, P., Heinze, C., Ilyina, T., Séférian, R., Tjiputra, J., and Vichi, M.: Multiple stressors of ocean ecosystems in the 21st century: projections with CMIP5 models, Biogeosciences, 10, 6225-6245, doi:10.5194/bg-10-6225-2013, 2013.

Braconnot, P., Harrison, S. P., Kageyama, M., Bartlein, P. J., Masson-Delmotte, V., Abe-Ouchi, A., Otto-Bliesner, B., and Zhao, Y.: Evaluation of climate models using palaeoclimatic data, Nat. Clim. Change, 2, 417-424, 2012.

Broecker, W. S., Spencer, D. W., and Craig, H.: Geosecs Pacific Expedition. vol. 3, Hydrographic Data 1973-1974, Superintendent of documents, U.S. government printing office, Washington D.C., 137 pp., 1982.

Buesseler, K. O. and Boyd, P. W.: Will ocean fertilisation work?, Science, 300, 67-68, 2003.

Buitenhuis, E., Le Quéré, C., Aumont, O., Beaugrand, G., Bunker, A., Hirst, A., Ikeda, T., O’Brien, T., Piontkovski, S., and Straile, D.: Biogeochemical fluxes through mesozooplankton, Global Biogeochem. Cy., 20, GB2003, doi:10.1029/2005GB002511, 2006.

Buitenhuis, E., Rivkin, R., Sailley, S., and Le Quere, C.: Biogeochemical fluxes through microzooplankton, Global Biogeochem. Cy., 24, GB4015, doi:10.1029/2009GB003601, 2010.

Buitenhuis, E. Vogt, M., Moriarty, R., Bednaršk, N., Doney, S., Leblanc, K., Le Quéré, C., Luo, Y. -W., O’Brien, C., O’Brien, T., Peloquin, J. Schiebel, R., and Swan, C.: MAREDAT: towards a world atlas of MARine Ecosystem DATa, Earth System Science Data, 5, 227-239, 2013.

Carr, M. -E., Friedrichs, M. A. M., Schmeltz, M., Aita, M. N., Antoine, D., Arrigo, K. R., Asanuma, I., Aumont, O., Barber, R., Behrenfeld, M., Bidigare, R., Buitenhuis, E. T., Campbell, J., Ciotti, A., Dierssen, H., Dowell, M., Dunne, J., Esaias, W., Gentili, B., Gregg, W., Groom, S., Hoepffner, N., Ishizaka, J., Kameda, T., Le Quéré, C., Lohrenz, S., Marra, J., Mélin, F., Moore, K., Morel, A., Reddy, T. E., Ryan, J., Scardi, M., Smyth, T., Turpie, K., Tilstone, G., Waters, K., and Yamanaka, Y.: A 
comparison of global estimates of marine primary production from ocean color, Deep-Sea Res.-Pt. II, 53, 741-770, 2006.

Cheung, W. W. L., Sarmiento, J. L., Dunne, J. P., Frölicher, T. L., Lam, V. W. Y., Palomares, M. L. D., Watson, R. and Pauly, D.: Shrinking of fishes exacerbates impacts of global ocean changes on marine ecosystems, Nat. Clim. Change, 3, 254-258, 2012.

Condon, R., Duarte, C. M., Pitt, K. A., Robinson, K., Lucas, C. H., Sutherland, K. R., Mianzan, H. W., Bogeberg, M., Purcell, J. E., Decker, M. B., Uye, S., Madin, L. P., Brodeur, R. D., Haddock, S. H. D., Malej, A., Parry, G. D., Eriksen, E., Quiñones, J. Acha, M., Harvey, M., Arthur, J. M., and Graham, W. M. :Recurrent jellyfish blooms are a consequence of global oscillations, P. Natl. Acad. Sci. USA, 110, 1000-1005, 2013.

Collins, W. J., Bellouin, N., Doutriaux-Boucher, M., Gedney, N., Halloran, P., Hinton, T., Hughes, J., Jones, C. D., Joshi, M., Liddicoat, S., Martin, G., O'Connor, F., Rae, J., Senior, C., Sitch, S., Totterdell, I., Wiltshire, A., and Woodward, S.: Development and evaluation of an Earth-System model - HadGEM2, Geosci. Model Dev., 4, 1051-1075, doi:10.5194/gmd-4-10512011, 2011.

Cox, P. M., Betts, R. A., Jones, C. D., Spall, S. A., and Totterdell, I. J.: Acceleration of global warming due to carbon-cycle feedbacks in a coupled climate model, Nature, 408, 184-187, 2000.

Dickson, A. G. and Goyet, C.: Handbook of methods for the analysis of the various parameters of the carbon dioxide system in sea water, Version 2 (No. ORNL/CDIAC-74).,Oak Ridge National Lab., TN (United States), 1994.

Doney, S. C., Lima, I., Moore, J. K., Lindsay, K., Behrenfeld, M. J., Westberry, T. K., Mahowald, N., Glover, D. M., and Takahashi, T.: Skill metrics for confronting global upper ocean ecosystembiogeochemistry models against field and remote sensing data, Skill assessment for coupled biological/physical models of marine systems, J. Mar. Syst., 76, 95-112, 2009.

Dunne, J. P., Sarmiento, J. L., and Gnanadesikan A.: A synthesis of global particle export from the surface ocean and cycling through the ocean interior and on the seafloor, Global Biogeochem. Cy., 21, GB4006, doi:10.1029/2006GB002907, 2007.

Edmond, J. M. and Gieskes, J. M. T. M.: On the calculation of the degree of saturation of sea water with respect to calcium carbonate under in situ conditions, Geochim. Cosmochim. Ac., 34, 1261-1291, 1970.

Friedrichs, M. A. M., Dusenberry, J. A., Anderson, L. A., Armstrong, R. A., Chai, F., Christian, J. R., Doney, S. C., Dunne, J., Fujii, M., Hood, R., McGillicuddy, D. J., Moore, J. K., Schartau, M., Spitz, Y. H., and Wiggert, J. D.: Assessment of skill and portability in regional marine biogeochemical models: Role of multiple planktonic groups, J. Geophys. Res.-Oceans, 112, C08001, doi:10.1029/2006JC003852, 2007.

Garcia, H. E., Locarnini, R. A., Boyer, T. P., Antonov, J. I., Baranova, O. K., Zweng, M. M., and Johnson, D. R.: World Ocean Atlas 2009, Volume 3: Dissolved Oxygen, Apparent Oxygen Utilization, and Oxygen Saturation, edited by: Levitus, S., NOAA Atlas NESDIS 70, US Government Printing Office, Washington DC, 344 pp., 2010a.

Garcia, H. E., Locarnini, R. A., Boyer, T. P., Antonov, J. I., Zweng, M. M., Baranova, O. K., and Johnson, D. R.: World Ocean Atlas 2009, Volume 4: Nutrients (phosphate, nitrate, silicate), edited by: Levitus, S., NOAA Atlas NESDIS 71, US Government Printing Office, Washington DC, 398 pp., 2010b.
Gaspar, P., Grégoris, Y., and Lefevre, J.-M.: A simple eddy kinetic energy model for simulations of the oceanic vertical mixing: Tests at station Papa and long-term upper ocean study site, J. Geophys. Res.-Oceans, 95, 16179-16193, 1990.

Glibert, P. M., Allen, J. I., Artioli, Y., Beusen, A., Bouwman, L., Harle, J., Holmes, R., and Holt, J.: Vulnerability of coastal ecosystems to changes in harmful algal bloom distribution in response to climate change: projections based on model analysis, Global Change Biol., 20, 3845-3858, doi:10.1111/gcb.12662, 2014.

Halloran, P. R., Bell, T. G., and Totterdell, I. J.: Can we trust empirical marine DMS parameterisations within projections of future climate?, Biogeosciences, 7, 1645-1656, doi:10.5194/bg-71645-2010, 2010.

Harvey, L. D. D.: Mitigating the atmospheric $\mathrm{CO}_{2}$ increase and ocean acidification by adding limestone powder to upwelling regions, J. Geophys. Res.-Oceans, (1978-2012), 113, C04028, doi:10.1029/2007JC004373, 2008.

Hewitt, H. T., Copsey, D., Culverwell, I. D., Harris, C. M., Hill, R. S. R., Keen, A. B., McLaren, A. J., and Hunke, E. C.: Design and implementation of the infrastructure of HadGEM3: the nextgeneration Met Office climate modelling system, Geosci. Model Dev., 4, 223-253, doi:10.5194/gmd-4-223-2011, 2011.

Hunke, E. C. and Lipscomb, W. H.: CICE: The los alamos sea ice model, documentation and software user's manual, version 4.0, Los Alamos National Laboratory Tech. Rep. LA-CC-06, 2008.

Jackson , D. A., Peres-Neto, P. R., and Olden. J. D.: What controls who is where in freshwater fish communities - the roles of biotic, abiotic, and spatial factors, Can. J. Fish. Aquat. Sci., 58, 157$170,2001$.

Jolliff, J. K., Kindle, J. C., Shulman, I., Penta, B., Friedrichs, M. A. M., Helber, R., and Arnone, R.A.: Summary diagrams for coupled hydrodynamic-ecosystem model skill assessment, J. Marine Syst., 76, 64-82, 2009.

Key, R. M., Kozyr, A., Sabine, C. L., Lee, K., Wanninkhof, R., Bullister, J. L., Feely, R. A., Millero, F. J., Mordy, C., and Peng, T.-H.: A global ocean carbon climatology: results from Global Data Analysis Project (GLODAP), Global Biogeochem. Cy., 18, GB4031, doi:10.1029/2004GB002247, 2004.

Kheshgi, H. S.: Sequestering atmospheric carbon dioxide by increasing ocean alkalinity, Energy, 20, 915-922, 1995.

Kriest, I., Khatiwala, S., and Oschlies, A.: Towards an assessment of simple global marine biogeochemical models of different complexity, Prog. Oceanogr., 86, 337-360, 2010.

Large, W. and Yeager, S.: The global climatology of an interannually varying air-sea flux data set, Clim. Dynam., 33, 341-364, 2009.

Le Quéré, C., Harrison, S. P., Prentice, I. C., Buitenhuis, E. T., Aumont, O., Bopp, L., Claustre, H., Da Cunha, L. C., Geider, R., Giraud, X., Klaas, C., Kohfeld, K. E., Legendre, L., Manizza, M., Platt, T., Rivkin, R. B., Sathyendranath, S., Uitz, J., Watson, A. J., and Wolf-Gladrow, D.: Ecosystem dynamics based on plankton functional types for global ocean biogeochemistry models, Glob. Change Biol., 11, 2016-2040, doi:10.1111/j.13652486.2005.1004.x, 2005.

Lévy, M., Resplandy, L., Klein, P., Capet, X., and Ethé, C.: Grid degradation of submesoscale resolving ocean models: benefits for offline passive tracer transport, Ocean Model., 48, 1-9, 2012. 
Locarnini, R. A., Mishonov, A. V., Antonov, J. I., Boyer, T. P., Garcia, H. E., Baranova, O. K., Zweng, M. M., and Johnson, D. R.: World ocean atlas 2009, volume 1: Temperature, in: NOAA Atlas NESDIS 68, edited by: Levitus, S., US Government Printing Office, Washington, DC, USA, 184 pp., 2010.

Madec, G.: NEMO reference manual, ocean dynamic component: NEMO-OPA, Note du Pôle de modélisation, Institut Pierre Simon Laplace, Technical Report 27, Note du pôle de modélisation, Institut Pierre Simon Laplace, France, No. 27, ISSN No. 1288-1619, 2008.

Monterey, G. and Levitus, S.: Seasonal Variability of Mixed Layer Depth for theWorld Ocean, NOAA Atlas NESDIS 14, US Gov. Printing Office, Washington DC, 96 pp., 1997.

Nightingale, P., Malin, G., Law, C., Watson, A., Liss, P., Liddicoat, M., Boutin, J., and Upstill-Goddard, R.: In situ evaluation of airsea gas exchange parameterizations using novel conservative and volatile tracers, Global Biogeochem. Cy., 14, 373-387, 2000.

O'Reilly, J. E., Maritorena, S., Mitchell, B. G., Siegal, D. A., Carder, K. L., Garver, S. A., Kahru, M., and McClain, C.: Ocean color chlorophyll algorithms for SeaWiFS, J. Geophys. Res., 103, 24937-24953, 1998.

Palmer, J. R. and Totterdell, I. J.: Production and export in a global ocean ecosystem model, Deep-Sea Res.-Pt I, 48, 1169-1198, 2001.

Popova, E.E., Yool, A., Coward, A.C., Dupont, F., Deal, C., Elliott, S., Hunke, E., Jin, M., Steele, M., and Zhang, J.: What controls primary production in the Arctic Ocean? Results from an intercomparison of five general circulation models with biogeochemistry. J. Geophys. Res.-Oceans 117, C00D12, doi:10.1029/2011JC007112, 2012.

Reid, P. C., Fischer, A. C., Lewis-Brown, E., Meredith, M. P., Sparrow, M., Andersson, A. J., Antia, A., Bates, N. R., Bathmann, U., Beaugrand, G., Brix, H., Dye, S., Edwards, M., Furevik, T., Gangstø, R., Hátún, H., Hopcroft, R. R., Kendall, M., Kasten, S., Keeling, R., Le Quéré, C., Mackenzie, F. T., Malin, G., Mauritzen, C., Ólafsson, J., Paull, C., Rignot, E., Shimada, K., Vogt, M., Wallace, C., Wang, Z., and Washington, R.: Chapter 1 Impacts of the Oceans on Climate Change, Adv. Mar. Biol., 56, $1-150,2009$.

Siddorn, J. R., Allen, J. I.,Blackford, J. C., Gilbert, F. J., Holt, J. T., Holt, M. W., Osborne, J. P., Proctor, R., and Mills, D. K.: Modelling the hydrodynamics and ecosystem of the North-West European continental shelf for operational oceanography, J. Mar. Syst., 65, 417-429, doi:10.1016/j.jmarsys.2006.01.018, 2007.
Steinacher, M., Joos, F., Frölicher, T. L., Bopp, L., Cadule, P., Cocco, V., Doney, S. C., Gehlen, M., Lindsay, K., Moore, J. K., Schneider, B., and Segschneider, J.: Projected 21st century decrease in marine productivity: a multi-model analysis, Biogeosciences, 7, 979-1005, doi:10.5194/bg-7-979-2010, 2010.

Stow, C. A., Jolliff, J., McGillicuddy Jr., D. J., Doney, S. C., Allen, J. I., Friedrichs, M. A. M., Rose, K. A., and Wallhead, P.: Skill assessment for coupled biological/physical models of marine systems, Skill assessment for coupled biological/physical models of marine systems, J. Mar. Syst., 76, 4-15, 2009.

Takahashi, T., Sutherland, S. C., Wanninkhof, R. Sweeney, C., Feely, R. A., Chipman, D. W., Hales, B., Friederich, G., Chavez, F., Sabine, C., Watson, A., Bakker, D. C. E., Schuster, U., Metzl, N., Yoshikawa-Inoue, H., Ishii, M. Midorikawa, T., Nojiri, Y., Kortzinger, A., Steinhoff, T., Hoppema, M., Olafsson, J., Arnarson, T. S., Tillbrook, B., Johannessen, T., Olsen, A., Bellerby, R., Wong, C. S., Delille, B., Bates, N. R., and de Baar, H. J. W.: Climatological mean and decade change in surface ocean $p \mathrm{CO}_{2}$, and net sea-air $\mathrm{CO}_{2}$ flux over the global oceans, Deep-Sea Res.Pt. II, 56, 554-577, doi:10.1016/j.dsr2.2008.12.009, 2009.

Taylor, K. E.: Summarizing multiple aspects of model performance in a single diagram, J. Geophys. Res., 106, 7183-7192, 2001.

Wanninkhof, R.: Relationship between wind speed and gas exchange over the ocean, J. Geophys. Res.-Oceans, 97, 7373-7382, 1992.

Westberry, T., Behrenfeld, M. J., Siegel, D. A., and Boss, E.: Carbon-based primary productivity modeling with vertically resolved photoacclimation, Global Biogeochem. Cy., 22, GB2024, doi:10.1029/2007GB003078, 2008.

Yool, A., Popova, E. E., and Anderson, T. R.: Medusa-1.0: a new intermediate complexity plankton ecosystem model for the global domain, Geosci. Model Dev., 4, 381-417, doi:10.5194/gmd-4381-2011, 2011.

Yool, A., Popova, E. E., and Anderson, T. R.: MEDUSA-2.0: an intermediate complexity biogeochemical model of the marine carbon cycle for climate change and ocean acidification studies, Geosci. Model Dev., 6, 1767-1811, doi:10.5194/gmd-6-17672013, 2013. 